\title{
DIGITAL SYSTEM BLOCKCHAIN SEBAGAI STRATEGI UNTUK OPTIMALISASI PENGELOLAAN DANA ZAKAT: STUDI KONSEPTUAL
}

\author{
Khalida Urfiyya ${ }^{\mathrm{a}, 1}$, Sulastiningsih ${ }^{\mathrm{b}, 2}$ \\ ${ }^{a}$ Universitas Islam Negeri Sunan Kalijaga, Yogyakarta 55281, Indonesia \\ ${ }^{b}$ Sekolah Tinggi Ilmu Ekonomi Widya Wiwaha, Yogyakarta 55162, Indonesia \\ ${ }^{1}$ khalidaurfiyya@gmail.com; ${ }^{2}$ Sulastiningsih@stieww.ac.id
}

\section{ARTICLE INFO}

Article history:

Received : 2021-08-03

Revised : 2021-09-24

Accepted : 2021-12-01

\section{Keywords:}

Blockchain Technology

Zakat Potential

Zakat Empowerment

Economic Growth
Kata kunci:

Teknologi blockchain

Potensi Zakat

Pemberdayaan Zakat

Pertumbuhan Ekonomi

\section{ABSTRACT}

Digitalization is a new phenomenon in the early twenty-first century connecting technology with civilization and benefits mankind in an intelligent and efficient way. The adoption of the blockchain concept in zakat institutions is the time to be a solution in dealing with existing Islamic problems such as the collection and distribution of zakat funds. This study was to provide an overview of the opportunities, potential and capabilities of blockchain system adoption in zakat institutions, especially in Indonesia. The method was a literature study by reviewing various relevant literatures and balanced with related studies on phenomena in various countries. With dynamic technological developments, especially the emergence of blockchain technology, the zakat ecosystem can be further enhanced since blockchain offerred the concept of data decentralization which were permanent, real-time, secure and transparent. Several things to encourage this practice could be done by increasing the capabilities of zakat institutions' human resources, increasing awareness of compulsory zakat and the concept of digitizing zakat, integrated cooperation between OPZs, and collaborating with various digital platforms.

\section{ABSTRAK}

Digitalisasi adalah fenomena baru di awal abad kedua puluh satu yang menghubungkan antara teknologi dengan peradaban dan memberi manfaat bagi umat manusia dengan cara cerdas dan efisien. Pengadopsian konsep blockchain pada lembaga zakat sudah saatnya dapat menjadi solusi dalam menangani permasalahan - permasalahan keislaman yang ada seperti pada pengumpulan dan pendistribusian dana zakat. Penelitian ini bertujuan untuk memberikan gambaran atas peluang, potensi dan kemampuan adopsi sistem blockchain pada institusi zakat, terutama di Indonesia. Metodologi yang digunakan adalah studi pustaka dengan mengkaji berbagai literatur yang relevan serta diimbangi dengan studi - studi terkait pada fenomena diberbagai negara. Dengan perkembangan teknologi yang dinamis terutama munculnya teknologi blockchain, ekosistem zakat dapat lebih ditingkatkan karena blockchain menawarkan konsep desentralisasi data yang permanen, real-time, aman dan transparan. Beberapa hal yang dapat diupayakan dalam mendorong praktik ini adalah dengan peningkatan kapabilitas SDM lembaga zakat, peningkatan kesadaran wajib zakat dan konsep digitalisasi zakat, kerjasama terintgritas antar OPZ, serta melakukan kerja sama dengan berbagai platform digital. 


\section{Pendahuluan}

Zakat adalah bentuk dari salah satu rukun Islam sebagai wujud aksi sosial yang harus dilakukan oleh setiap muslim. Zakat dapat membersihkan jiwa dari keserakahan, keegoisan dan kikir, memurnikan harta dari hak orang lain dan memberikan dampak positif bagi ekonomi masyarakat dengan cara mengurangi tingkat kemiskinan, meningkatkan pertumbuhan ekonomi, serta meningkatkan keseimbangan daya beli masyarakat (Rahim \& Kaswadi, 2014). Zakat menjadi salah satu bentuk ibadah ekonomi dan sosial yang mampu mengurangi ketimpangan di masyarakat. Pengelolaan dana zakat yang baik dan tepat dapat mewujudkan distribusi pendapatan yang merata.

Awal abad ke-21 telah membawa revolusi besar pada teknologi dan sains dunia. Mulai dari akhir dekade pertama pada abad ke-21, kemajuan teknologi telah menyatu dengan sektor jasa keuangan yang kemudian meluas dengan masuknya inovasi teknologi pada sektor keuangan, perbankan, ritel, pendidikan dan institusi sosial. Laporan penelitian dari The Deutsche Bank (Dapp, 2014), menggambarkan pergerakan pada sektor Financial Technology (FinTech) digambarkan sebagai digitalisasi dalam sektor keuangan, dimana sebagian besar teknologi berbasis internet di sektor keuangan. Inovasi pada sektor Fintech semakin meluas dan populer, misalnya pada akses rekening bank yang sebelumnya terbatas, menjadi lebih praktis dengan adanya mobile banking, e-money dan lain sebagainya. Inovasi ini juga terlihat pada segi lembaga sosial, seperti lembaga ZISWAF (zakat, infak, shodaqah dan wakaf) yang mulai meletakkan digital assistant sebagai penunjangnya.

Di sisi lain, dari sekitar 1,8 miliar populasi di seluruh dunia, Islam adalah agama dengan pertumbuhan tercepat di dunia. Jumlah Muslim diproyeksikan melebihi kelompokkelompok Kristen di tahun-tahun mendatang (Lipka \& Conrad, 2017). Salah satu efek dari peningkatan populasi ini adalah meningkatnya permintaan akan produk yang sesuai dengan sumber hukum umat Islam, terutama pada negara yang memiliki mayoritas penduduk Muslim seperti Indonesia. Sehingga, konsep transaksi keuangan modern yang memegang aspek syariah harus memiliki ciri yang transparan, menguntungkan bagi kedua belah pihak, dan yang paling utama yaitu sesuai dengan ketentuan-ketentuan syariat islam.

Selain pada potensi perkembangan yang ditunjang oleh aspek media digital pada lembaga zakat, potensi lain terlihat dari besarnya dana ZISWAF yang terus mengalami peningkatan dari tahun ke tahun. Sampai dengan tahun 2018, diperkirakan penerimaan zakat dalam 5 tahun tumbuh dengan rata-rata sebesar 26,64\% (Komite Nasional Keuangan Syariah, 2019).

Data penerimaan zakat oleh BAZNAS (Badan Amil Zakat Nasional) menunjukkan bahwa selama 5 tahun sejak 2015 hingga 2019 , dana zakat yang berhasil terkumpul meningkat sebesar $64,2 \%$, dari yang semula Rp 3.70 triliyun menjadi 10.12 triliyun di tahun 2019. Selain itu, data IPPZ (Indikator Potensi Pemetaan Zakat), menunjukkan bahwa potensi penerimaa zakat di Indonesia secara nasional pada tahun 2019 mencapai Rp 233.84 triliun atau sebesar $\$ 15.91$ billion. Dari data tersebut menunjukkan bahwa indikator dengan nilai potensi zakat paling tinggi adalah sektor zakat penghasilan dengan nilai sebesar Rp. 139.07 triliun, yang selanjutnya disusul sebesar Rp. 58.76 triliun pada zakat uang, zakat pertanian Rp. 19.79 triliun dan zakat peternakan sebesar Rp. 9.51 triliun (Badan Amil Zakat Nasional, 2020).

Di sisi lain, sesuatu yang disayangkan adalah dalam realisasinya, penerimaan dana zakat masih belum optimal. Menurut BAZNAS, perolehan dana zakat pada tahun 2019 baru mencapai Rp. 10,07 triliun atau $4,31 \%$ dari potensi yang dimilikinya yaitu $R p$. 233,84 triliun. Dari basarnya potensi yang ada, baru sebesar 3,5\% atau sekitara Rp. 8 triliun yang bisa dikelola oleh lembaga zakat (Badan Amil Zakat Nasional, 2020). Apabila dana zakat dihimpun dan dikelola dengan baik oleh amil yang amanah, terpercaya dan professional, serta didistribusikan dengan baik dan merata, maka zakat sejatinya dapat menanggulangi kemiskinan di masyarakat. Secara empirik, hal tersebut telah dibuktikan dalam sejarah, yaitu pada masa pemerintahan Umar bin Abdul Aziz, dimana dana zakat yang dikelola oleh amil dapat mengurangi tingkat kemiskinan dalam waktu relatif singkat (Shalihati, 2010). 
Selain berpotensi dapat memberikan kesejahteraan dan meningkatkan kualitas sosial masyarakat pada taraf mikro ekonomi, dana zakat juga memiliki potensi yang besar dalam pembangunan ekonomi. Ahmed Shaikh \& Ismail (2017) menyatakan bahwa rasio zakat terhadap PDB melebihi rasio indeks kesenjangan kemiskinan terhadap PDB, kecuali pada 3 negara dengan garis kemiskinan yang ditetapkan sebesar $\$ 1,25$ sehari. Artinya, agregat sumber daya yang dikumpulkan dari pengumpulan zakat potensial di 17 negara Organisasi Kerja Sama Islam (OKI) akan cukup untuk mendanai sumber daya pengentasan kemiskinan di semua 17 negara OKI jika digabungkan.

Mahat dan Warokka (2013), menyatakan bahwa pemerintah negara-negara muslim harus sungguh-sungguh memperhatikan optimalisasi penggunaan zakat sebagai sumber dana investasi untuk pertumbuhan dan pembangunan ekonomi, yang sebagian besar diyakini bahwa zakat memberikan keadilan sosial ekonomi yang lebih adil dan pemerataan kekayaan. Menurut Yusoff (2011), zakat berpengaruh positif terhadap pertumbuhan ekonomi di Malaysia sedangkan menurut Azam et al. (2014) zakat dapat meningkatkan kesejahteraan rumah tangga dan berkontribusi pada pertumbuhan ekonomi di Pakistan.

Dalam tahapan menuju era 4.0, Indonesia telah mampu beradabtasi dengan penggunaan financial technology. Lebih luas, penggunaan Robotics Process Automation (RPA), Artificial Intelligent (AI), dan Internet of Things (IoT), yang termasuk didalamnya adalah blockchain, dapat merubah tatanan seluruh industri secara fundamental dengan cepat. Hal ini dikarenakan teknologi tersebut mampu memberikan manfaat yang besar dalam meningkatkan kinerja Industri menuju performa yang lebih baik dengan biaya yang efisien. Sebagai lembaga yang mengelola dana publik, keberadaan teknologi seperti penggunaan blockchain akan sangat membantu Organisasi Pengelola Zakat (OPZ) dalam meningkatkan efisensi, transparansi, dan akuntabilitas.

Beberapa penelitian telah membahas mengenai konsep blockchain dan penerapannya pada lembaga nirlaba di suatu negara. Teerlink (2019) melakukan penelitian mengenai penerapan sistem blockchain pada organisasi non-profit Non-Government Organizations (NGOs) atau yang sering disebut Lembaga Swadaya Masyarakat (LSM), menyebutkan bahwa terdapat beberapa potensi utama dari penerapan sistem blockchain, yaitu peningkaan akuntabilitas dan transparansi pada penyimpan data transaksi dan aktivitas, smart contract dengan pendanaan basis jangka waktu yang dapat menigkatkan kepercayaan pendonasi, dan dapat menciptakan tolak ukur terhadap LSM yang kemudian meningkatkan efektifitas penyebaran dana antar LSM, dapat meningkatkan standar pelaporan. United Nations (2020) mencoba menerapkan sistem blockchain pada 10 bidang organisasi untuk berbagai project dan operasi dengan tujuan melihat efektifitas dari sistem tersebut. Temuan paling optimis dari uji coba tersebut adalah bahwa tahun-tahun pertama penerapan blockchain pada sistem Persatuan BangsaBangsa (PBB) dapat mengkonfirmasi adanya hubungan kerjasama yang baik dan sehat antar lembaga pada organisasi. Selanjutnya, Santoso et al. (2020) melakukan penelitian mengenai penerapan sistem blockchain pada pengelolaan zakat dengan mengambil sampel sebanyak 200 responden yang terdiri dari akademisi, aktivis ekonomi islam, amil zakat dan mahasiswa. Hasil penelitian menyatakan bahwa Information and Communication Technology (ICT) dapat meningkatkan kesadaran orang dalam berzakat dan penggunaan sistem blockchain dapat meningkatkan nilai kredibilitas lembaga zakat. Selain itu, transparansi dapat mendorong dan meningkatkan kepercayaan masyarakat terhadap lembaga zakat.

Berdasarkan berbagai latar belakang yang telah dipaparkan, menjadi menarik untuk mengkaji lebih lanjut mengenai urgensi dan potensi penerapan sistem blockchain pada lembaga zakat, terutama di Indonesia. Penelitian ini mencoba untuk mengkaji lebih dalam dan melihat seberapa besar potensi dan kemampuan pertumbuhan dana zakat dengan bantuan teknologi digital dan didukung sistem blockchain yang dihubungkan dengan fenomena dan regulasi berfokus di negara Indonesia. Penelitian ini diimbangi dengan melihat studi-studi terkait dari fenomena di berbagai negara. 


\section{Tinjauan Pustaka}

Zakat merupakan instrumen kemakmuran dari sisi sosial dan ekonomi. Dengan pemerataan ekonomi melalui pengurangan konsentrasi kekayaan, kohesi sosial akan meningkat. Ketika ketimpangan pendapatan mengusik tatanan sosial negara, termasuk pada negara-negara Muslim dan menghambat pertumbuhan ekonomi yang sehat, membangun sistem zakat yang efisien menjadi sebuah kebutuhan. Dalam penelitian Salleh et al. (2019) menyebutkan bahwa peningkatan efisiensi zakat dengan merangkul perkembangan teknologi terkini dan mengadaptasi blockchain sebagai tolok ukur dalam menjaga transaksi yang aman, transparan, dan hemat biaya, diharapkan dapat menciptakan disrupsi positif di sektor zakat.

Blockchain adalah sistem database terdistribusi terbuka yang melakukan transaksi pada buku besar terdesentralisasi, di mana setiap pihak memiliki akses terhadap data (Nor, Rahman, Rahman, \& Abdullah, 2017). Lebih khusus, blockchain merupakan rantai data transaksi antara pengguna yang disimpan dalam blok di mana setiap blok mencatat sejumlah data tertentu yang dienkripsi berkat hashing kriptografi. Ketika seorang pengguna ingin melakukan transaksi, ia harus mengomunikasikannya kepada semua pengguna jaringan lain sehingga mereka dapat memverifikasi keaslian operasi. Setiap pengguna akan memiliki salinan buku besar data, sehingga semua transaksi terlihat dan tersedia untuk seluruh pihak dan tidak mungkin terjadi transaksi palsu, tindakan penipuan, atau operasi peretasan. Selain transparansi, keandalan, dan kemungkinan pelacakan dana yang tepat dan terperinci, struktur jaringan blockchain yang terdesentralisasi juga dapat mengurangi biaya transaksi dengan menghilangkan perantara apa pun dalam proses transaksi (Rejeb, 2020).

Blockchain sebagai sistem manajemen dapat menjadi alat bantu lembaga zakat dalam perencanaan dan pengendalian funding dan distributing. Konsep dari blockchain yang merupakan rantai penghubung aktivitas stakeholder dengan manajer tidak terdapat unsur-unsur non-syar'i didalamnya. Aktivitas ini justru dapat memberikan maslahah untuk seluruh pihak. Dengan demikian, hukum blockchain diperbolehkan. Salah satu kaidah yang menjadi arahan Rasulullah SAW adalah memudahkan.

Berikut beberapa hadits Rasulullah SAW yang dapat dijadikan sandaran hukum mengenai halalnya penerapan blockchain:

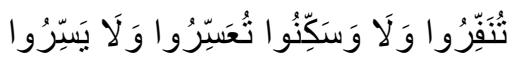

"Permudahlah oleh kalian dan jangan mempersulit, buatlah hati mereka tenang dan jangan menakut-nakuti." (HR. Muslim, No. 3263).

$$
\begin{aligned}
& \text { خُبِرِ مَا قَالَتْ أَنَّهَا عَنْهَا اللَّهُ رَضِيَ عَائشِتَةَ عَنْ }
\end{aligned}
$$

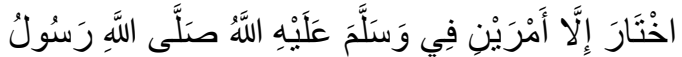

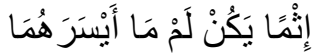

"Dari 'Aisyah radliallahu 'anha ia berkata, "Tidaklah Rasulullah shallallahu 'alaihi wasallam diberi dua pilihan kecuali beliau memilih yang paling mudah dari keduanya selama tidak termasuk dosa" (HR. Abu Daud, No. 4153).

$$
\begin{aligned}
& \text { أَنَّ جَدِّهِ عَنْ أَبِيهِ عَنْ الْمُزَنِيٌْ عَوْفٍ بْنِ عَمْرِو }
\end{aligned}
$$

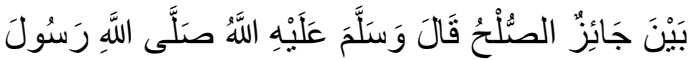

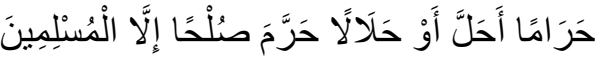

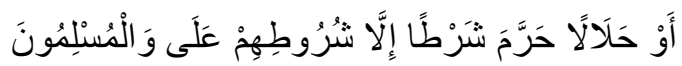

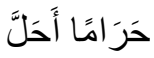

"Dari 'Amr bin 'Auf al-Muzani dari ayahnya dari kakeknya, bahwa Rasulullah shallallahu 'alaihi wasallam bersabda: Sulh (penyelesaian sengketa melalui musyawarah untuk mufakat) dapat dilakukan di antara kaum muslimin kecuali sulh yang mengharamkan yang halal atau menghalalkan yang haram. Dan kaum muslimin terikat dengan syarat-syarat mereka kecuali syarat yang mengharamkan yang halal atau menghalalkan yang haram." (HR. Al-Tirmidzi, No. 1272).

Berdasarkan hadits-hadits tersebut dapat disimpulkan bahwa penggunaan blockchain dalam optimalisasi pengelolaan dana zakat dapat memberikan nilai tambah kepada lembaga, sehingga kemanfaatan dana zakat menjadi semakin luas.

\section{Metodologi Penelitian}

Penelitian ini merupakan penelitian deskriptif kualitatif yang dilakukan melalui kajian pustaka mendalam terkait dengan 
digitalisasi zakat melalui sistem blockchain. Penelitian ini berupaya untuk menyajikan dan menggambarkan urgensi dan potensi optimalisasi pengelolaan dana zakat serta kontribusinya terhadap perekonomian yang disertai dengan ilustrasi model digitalisasi sistem blockchain. Lebih jauh, peneltian ini bertujuan untuk memperlihatkan kepada masyarakat, pemangku kepentingan dan organisasi pengelolaan zakat atas kesiapan Indonesia dan bersama-sama mendukung kemajuan pengelolaan zakat di Indonesia.

Respon Lembaga zakat salah satunya ditunjukkan oleh BAZNAS yang saat ini sedang dalam proses menerapkan teknologi bolckchain. Diproyeksikan BAZNAS mampu menerapkan secara lengkap pada seluruh fitur blockchain termasuk dalam membangun networking pada tiga tahun mendatang.

\section{Hasil dan Diskusi}

\section{a. Tingkat Pertumbuhan Populasi Muslim di Dunia}

Dalam Pew Research Center's Forum on Religion and Public Life menyebutkan bahwa jumlah populasi muslim di dunia diproyeksikan akan mengalami peningkatan sebesar 35\% pada tahun 2030 yaitu sebesar 2,2 miliar muslim yang terdiri dari segala golongan usia dapat ditemukan di seluruh dunia. Dalam penelitian lain dengan judul "The future of world religions: Population growth projections 2010-2050", menunjukkan umat beragama Islam adalah kelompok agama tertinggi yang akan meningkat jauh lebih cepat dari agama lain di dunia (Lipka \& Conrad, 2017).

Pew Research Center (2015) juga menyatakan bahwa tingkat kelahiran terbesar berasal dari kelompok muslim, yaitu dengan rata-rata 3,1 anak, yang berada di atas rata-rata yaitu 2,1 anak untuk menopang populasi kelahiran yang stabil. Laporan tersebut juga menyoroti bahwa pertumbuhan jumlah pemuda di bawah usia 15 tahun berjumlah $27 \%$ dari total populasi global. Dari total jumlah pemuda di seluruh dunia, 34\% terdiri dari pemuda Muslim, yang memberikan kontribusi tertinggi dibandingkan dengan kelompok pemuda dari agama lain. Migrasi merupakan salah satu faktor kuat yang mempengaruhi proporsi agama di suatu negara atau wilayah tertentu. Migrasi penduduk muslim di Eropa diperkirakan akan secara terus menerus meningkat dari 4,9 persen pada tahun 2015 menjadi 7,4 persen pada tahun 2050.

Selain itu, populasi muslim di Eropa diproyeksikan akan tumbuh sebesar 63 persen antara tahun 2010 hingga 2050. Selama periode tersebut, diperkirakan populasi Muslim di kawasan Asia Pasifik akan mengalami peningkatan sebesar 48 persen, sedangkan secara keseluruhan populasi kawasan akan meningkat sebesar 22 persen (Pew Research Center, 2015).

\section{Gambar 1}

Proyeksi Populasi Penduduk Muslim Terbesar di Dunia

\begin{tabular}{|c|c|c|c|c|c|}
\hline & $\begin{array}{l}2010 \text { MUSLIM } \\
\text { POPULATION }\end{array}$ & $\begin{array}{l}\text { \% OF WORLD'S } \\
\text { MUSLIM } \\
\text { POPULATION } \\
\text { IN } 2010\end{array}$ & & $\begin{array}{l}2050 \text { MUSLIM } \\
\text { POPULATION }\end{array}$ & $\begin{array}{l}\text { \% OF WORLD'S } \\
\text { MUSLIM } \\
\text { POPULATION } \\
\text { IN } 2050\end{array}$ \\
\hline 1 Indonesia & $209,120,000$ & $13.1 \%$ & 1 India & $310,660,000$ & $11.2 \%$ \\
\hline 2 India & $176,200,000$ & 11.0 & 2 Pakistan & $273,110,000$ & 9.9 \\
\hline 3 Pakistan & $167,410,000$ & 10.5 & 3 Indonesia & $256,820,000$ & 9.3 \\
\hline 4 Bangladesh & $134,430,000$ & 8.4 & 4 Nigeria & $230,700,000$ & 8.4 \\
\hline 5 Nigeria & $77,300,000$ & 4.8 & 5 Bangladesh & $182,360,000$ & 6.6 \\
\hline 6 Egypt & $76,990,000$ & 4.8 & 6 Egypt & $119,530,000$ & 4.3 \\
\hline 7 Iran & $73,570,000$ & 4.6 & 7 Turkey & $89,320,000$ & 3.2 \\
\hline 8 Turkey & $71,330,000$ & 4.5 & $8 \mathrm{Iran}$ & $86,190,000$ & 3.1 \\
\hline 9 Algeria & $34,730,000$ & 2.2 & 9 Iraq & $80,190,000$ & 2.9 \\
\hline 10 Morocco & $31,930,000$ & 2.0 & 10 Afghanistan & $72,190,000$ & 2.6 \\
\hline Subtotal & $1,053,010,000$ & 65.8 & Subtotal & $1,701,070,000$ & 61.6 \\
\hline $\begin{array}{l}\text { Subtotal for Rest } \\
\text { of World }\end{array}$ & $546,700,000$ & 34.2 & $\begin{array}{l}\text { Subtotal for Rest } \\
\text { of World }\end{array}$ & $1,060,410,000$ & 38.4 \\
\hline World Total & $1,599,700,000$ & 100.0 & World Total & $2,761,480,000$ & 100.0 \\
\hline
\end{tabular}

1.000. Pencuture of Word Religions: Population Growth Prop

(Sumber: Pew Research Center, 2015)

Gambar di atas memperlihatkan bahwa Indonesia merupakan negara dengan populasi muslim terbesar di dunia, dan diproyeksikan akan tetap menjadi salah satu negara dengan penduduk muslim terbesar hingga tahun 2050. Ziswaf (zakat, infaq, sedekah dan wakaf), sebagai aliran dana pendapatan umat muslim yang bertujuan untuk meningkatkan kualitas hidup masyarakat, semestinya dapat berkontribusi besar sesuai dengan tujuannya.

\section{b. Dana Zakat dan Kontribusinya Pada Pertumbuhan Ekonomi}

Banyak negara berkembang, termasuk negara-negara muslim, telah mendorong dan merumuskan strategi pembangunan untuk mencapai pembangunan ekonomi yang berkelanjutan dan meningkatkan taraf hidup masyarakatnya. Dalam perspektif Islam, pembangunan mempunyai peran penting 
dalam mengatasi kemiskinan. Pengendalian kemiskinan merupakan tanggung jawab moral dan sosial setiap orang yang tertuang dalam fikih muamalah.

Dalam Yusoff (2011), menyatakan bahwa zakat dapat digunakan sebagai alat penting untuk mendorong pembangunan manusia. Penyaluran dana zakat dengan tujuan pemberdayaan sumber daya manusia dapat mendorong kualitas hidup yang lebih baik bagi penerimanya, sehingga dapat dikatakan bahwa peningkatan zakat dalam jangka pendek dapat memberikan nilai positif pada peningkatan level sosial masyarakat dan kualitas pendidikan mustahiq. Sedangkan dalam jangka panjang, hal ini dapat menaikkan angka konsumsi, investasi, permintaan atas tenaga kerja, dan kemudian dapat merangsang mustahiq untuk menjadi muzzaki. Meningkatnya kehidupan sosial dapat diartikan sebagai harapan pembangunan masyarakat dan pendidikan dapat digunakan sebagai indikator untuk mengukur Indeks Pembangunan Manusia (HDI) (Badrudin, 2015; Stevans \& Session, 2008).

Islam memiliki solusi melalui penyaluran dana sosial, khususnya zakat dan Indonesia memiliki potensi besar dalam sektor dana sosial Islam. Pusat Kajian Strategis BAZNAS juga merilis di dalam Outlook Zakat Indonesia 2020 bahwa potensi zakat pada tahun 2019 mencapai Rp. 233,84 triliun. Di sisi lain, sebagai negara dengan jumlah populasi muslim terbesar di dunia, World Giving Index memberikan Indonesia predikat sebagai negara paling dermawan.

Data BAZNAS lebih lanjut menyebutkan bahwa perolehan zakat terus meningkat dan rata-rata tumbuh 36,2 persen selama periode 2002-2019. Tercatat bahwa pengumpulan dana zakat nasional tumbuh sekitar 24 persen dalam lima tahun terakhir, sehingga dapat dikatakan zakat menjadi instrumen yang amat potensial untuk membantu memenuhi kebutuhan dasar masyarakat miskin, khususnya di tengah pandemi seperti ini.

Dalam Undang-Undang (UU) Nomor 23 tahun 2011 mengenai Pengelolaan Zakat, menyebutkan bahwa pengelolaan zakat memiliki tujuan untuk meningkatkan efektifitas dan efisiensi pelayanan dalam pengelolaan zakat, serta berupaya untuk meningkatkan manfaat perolehan zakat yang kemudian dapat menciptakan kesejahteraan masyarakat dan menanggulangi kemiskinan.

Uraian UU tersebut menjelaskan bahwa proses pengelolaan dan distribusi dana zakat tidak hanya berujuan untuk mewujudkan kesejahteraan masyarakat miskin/ mustahiq, tetapi juga memiliki tujuan untuk meningkatkan nilai efisiensi dan efektivitas dari pelayanan lembaga dalam mengelola zakat yang dioperasionalkan oleh lembaga atau badan amil zakat.

Melalui perantara zakat, berbagai persoalaan di masyarakat baik berupa permasalahan sosial maupun ekonomi semestinya dapat diatasi. Dana zakat dapat didistribusikan pada program kerja produktif, misalnya pembiayaan pada unit usaha mikro, kecil dan menengah (UMKM), sehingga nantinya mustahiq dapat berdiri dan lepas dari kemiskinan. Sarea (2012) dalam penelitiannya, menyimpulkan bahwa zakat secara positif dapat memberikan pengaruh baik terhadap pertumbuhan ekonomi dalam hal penanggulangan kemiskinan, pengurangan pengangguran serta laju inflasi.

Sejauh ini penelitian mengenai potensi dan pengaruh dana zakat terhadap kesejahteraan masyarakat dan masalah-masalah sosial serta kajian mengenai realisasi riil dana zakat sering diteliti secara terpisah. Jauh sebelum masuknya era teknologi, Kahf (1987) telah memperkirakan adanya potensi zakat di 8 negara Islam yaitu Arab Saudi, Sudan, Suriah, Turki, Indonesia, Mesir, Pakistan dan Qatar. Penelitian ini mencoba mengestimasi potensi zakat melalui tiga cara, yaitu 1) fiqh tradisional, 2) perhitungan ala Qardawi dimana pendapatan zakat dihitung 2,5 persen dan laba bersih aktiva tetap dihitung sebesar 10 persen, dan 3) memodifikasi versi Qardawi yaitu, semua dana zakat baik yang berasal dari aktiva tetap maupun pendapatan sebesar 2,5 persen. Penelitian tersebut berkesimpulan bahwa potensi besaran zakat di Indonesia adalah antara 1 hingga 2 persen dari Produk Domestik Bruto (PDB).

Dari berbagai aspek dan fenomena zakat, telah banyak peneliti yang melakukan penelitian mengenai potensi kontribusi dana zakat pada pertumbuhan perekonomian. Kurniawati (2004), memperkirakan bahwa 
potensi zakat di Indonesia sebeasr Rp. 6,132 triliun. Firmansyah (2009) menggunakan asumsi tingkat zakat minimal 2,5 persen dari masing-masing sektor perekonomian daerah atau Produk Domestik Regional Bruto (PDRB), memperkirakan potensi zakat sebagai berikut, 1) tingkat zakat pertanian 2,5 persen dari nilai PDRB sektor pertanian, 2) tingkat zakat pertambangan 2,5 persen dari nilai PDRB sektor pertambangan, dan 3) tingkat zakat sektor lainnya masing-masing memiliki persentase 2,5 persen. Selanjutnya, penelitian Firdaus (2012) menyimpulkan dari berbagai sektor pendapatan seperti rumah tangga, perusahaan dan tabungan/investasi, potensi zakat di Indonesia diperkirakan mencapai Rp. 217 triliun atau setara dengan 3,4 persen dari PDB di Indonesia.

\section{c. Implikasi Penerapan Digital System Dalam Peningkatan Kinerja Lembaga Zakat}

Blockchain dibuat sebagai sistem pembukuan keuangan yang terdistribusi kuat, aman, dan transparan. Teknologi baru yang revolusioner ini juga merupakan teknologi yang tidak biasa karena meskipun secara nyata merupakan teknologi informasi dan komputasi, sebagai protokol perangkat lunak yang didasarkan pada kriptografi, blockchain adalah teknologi baru untuk database publik (Davidson, Filippi, \& Potts, 2016).

Definisi lain menyebutkan blockchain sebagai magic computer dimana setiap orang dapat mengunggah program dan membiarkan program berjalan sendiri. Status program dapat selalu terlihat oleh publik (terdesentralisasi) yang membawa jaminan keamanan kripto yang sangat kuat dan dijamin secara ekonomi bahwa program berjalan serta akan terus mengeksekusi persis seperti yang ditentukan oleh protokol blockchain (Buterin, 2015).

Pada sektor ekonomi Islam, implementasi asas digital pada sistem di berbagai sektor berpotensi dapat memudahkan dan dapat meningkatkan efisiensi serta efektivitas dari suatu lembaga. Dengan mengimplementasikan blockchain sebagai sistem dapat menjamin keamanan transaksi, transparansi dan efisiensi biaya. Selain itu blockchain dapat mengurangi kemungkinan adanya korupsi, penipuan dan risiko.
Implementasi blockchain dapat dimulai dengan memperkenalkan teknologi blockchain kepada para ulama Islam mengenai konsep, pengetahuan, dan mempelajari perspektifnya terhadap Maqasid al-Shari'ah.

Atribut dan konsep blockchain memiliki potensi yang signifikan untuk diterapkan dalam sistem keuangan islam karena beberapa hal, yaitu (Elasrag, 2019):

1. Transparansi: blockchain memberikan dan menampilkan sumber, ketertelusuran, dan transparansi dalam transaksi.

2. Kontrol: akses ke jaringan yang diizinkan dibatasi untuk pengguna yang diidentifikasi.

3. Kemananan: data keuangan dalam bentuk sistem pembukuan digital tidak dapat diubah atau dirusak setelah data dimasukkan. Kemungkinan penipuan sangat kecil dan lebih mudah untuk dilacak.

4. Informasi real-time: ketika informasi diperbarui, informasi itu secara langsung dan otomatis diperbarui untuk semua orang di jaringan pada waktu yang sama.

Penghimpunan dana zakat telah dilembagakan di banyak negara muslim. Promosi, pengumpulan dan distribusi zakat dilakukan oleh otoritas agama di masingmasing negara, sesuai dengan ketetapan syariah dan mulai mengarah pada pengadopsian sistem digital. Sebagai contoh, di Indonesia Badan Amil Zakat (BAZ) dan Lembaga Amil Zakat (LAZ) bekerjasama dengan penyedia jasa fintech melalui situs $e$ commerce dan dompet digital. Terhitung sejak tahun 2020, telah terdapat 8 lembaga zakat yang bekerjasama dengan situs penjualan online Tokopedia, Shopee dan e-commerce lainnya, antara lain BAZNAS, Rumah Yatim, Dompet Dhuafa, Rumah Zakat, LAZISMU, LAZ Al-Azhar, NU Care (LAZIS NU) dan Inisiatif Zakat Indonesia (IZI). Selain itu, trend donasi digital terbukti mengalami peningkatan. Aplikasi Gojek melalui platform GoZakat yang bekerjasama dengan LAZ, melaporkan pertumbuhan transaksi zakat meningkat 17 kali lipat terhitung sejak tahun 2019 (Komite Nasional Ekonomi dan Keuangan Syariah, 2020). 
Dalam suatu penelitian ditemukan beberapa permasalahan yang terjadi pada lembaga zakat antara lain adalah inefisiensi, kurangnya transparansi dalam hal bagaimana dana dikumpulkan, dikelola dan didistribusikan, serta perbedaan pandangan ulama tentang bagaimana hal ini harus ditangani dan masalah birokrasi yang luas.

Zakat adalah kewajiban amal tahunan bagi seluruh umat Islam. Kewajiban ini dihitung berdasarkan nilai cut-off indeks kehidupan dasar yang disebut nisab yang merupakan indeks standar hidup dasar masyarakat. Mereka yang kekayaan bersihnya di bawah batas ini dibebaskan dari membayar zakat. Sebaliknya, orang dengan kekayaan bersih lebih besar dari nisab selama setahun penuh memenuhi syarat wajib membayar zakat. Dengan mengadopsi blockchain dapat membuat prosesnya mudah dilacak, diaudit, dan tidak dapat diubah, yang semuanya merupakan kualitas penting dari setiap kesuksesan pengumpulan dana sosial.

\section{d. Keunggulan Model Blockchain}

Blockchain sebagai gudang rantai data yang saling terhubung, membutuhkan beberapa database primer untuk diinput ke dalam sistem yaitu, (1) data muzaki, (2) data mustahiq, (3) laporan donasi dana terkumpul, (4) laporan pendistribusian dana, dan (5) data amil pengelola. Selanjutnya dalam prosesnya, data yang sudah terkumpul akan di approve secara online dan dimasukkan ke dalam platform blockchain.

Pada model tradisional multi-system, data secara teknis dipercayakan kepada seseorang, sehingga transaksi dana zakat tidak dapat dilacak oleh berbagai pihak. Hal tersebut dapat memungkinkan risiko adanya manipulasi atau hacking pada sistem atau dana. Selain itu, lembaga zakat juga memerlukan biaya monitoring yang mahal karena di dalamnya perlu ada pengawasan dari berbagai pihak seperti auditor eksternal, pengawasan OJK, BI dan pihak keamanan.

Gambar II

Model Tradisional Penyaluran Dana Zakat

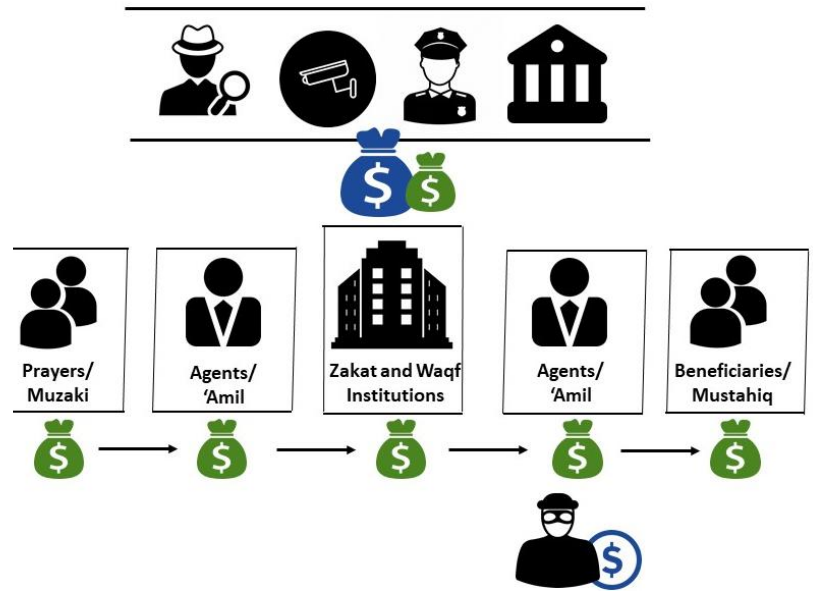

Pada sistem operasional dana zakat tradisional dapat ditemukan celah untuk terjadinya asymmetry information dan moral hazard. Kegiatan multi-system yang melibatkan banyak pihak mulai dari muzaki, amil, mustahiq dan lembaga pengawas menjadi sulit untuk dilacak kebenaran dan keabsolutan dari tiap tahapan transaksi. Data dengan sistem tersentralisasi sangat memungkinkan hal tersebut terjadi. Prakek yang merupakan peluang terjadinya ketidakjujuran dan ketidakhati-hatian yang dapat merugikan suatu lembaga atau organisasi, terutama organisasi Islam yang mengelola dana zakat, sangat perlu untuk dihindari.

\section{Gambar III}

Model Digitalisasi Blockchain Penyaluran Dana Zakat

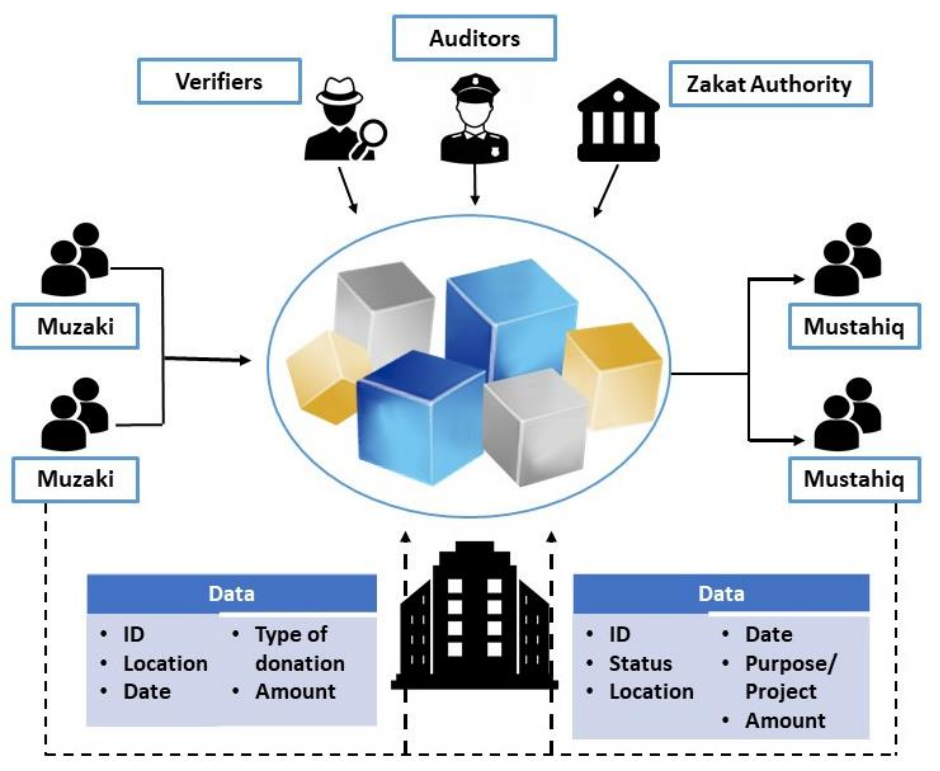

Selanjutnya, lebih mudah divisualisasikan dengan: 
Gambar IV

Visualisasi Perbandingan Model

Tradisional dan Digital

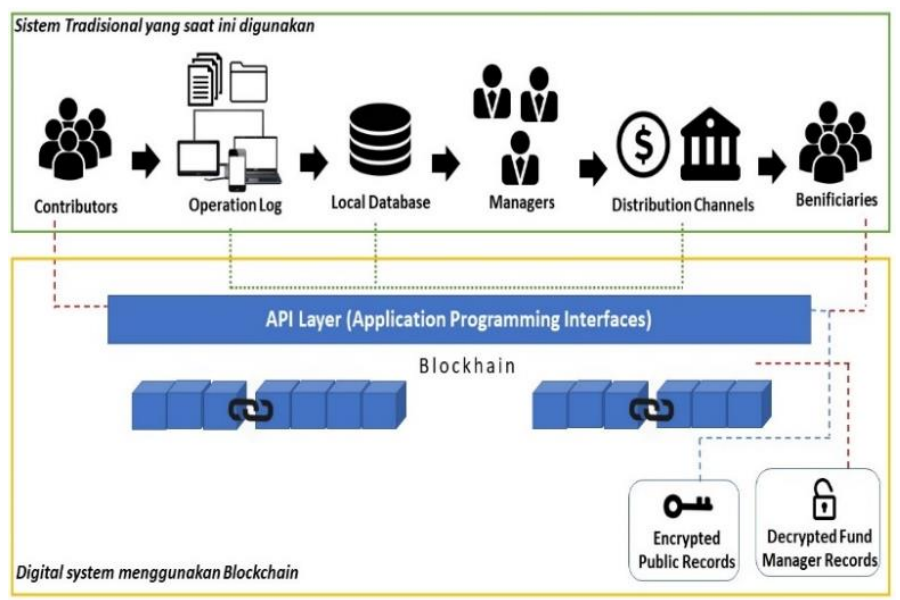

Tujuan dari penerapan blockchain adalah untuk mendobrak dinding antara berbagai pemangku kepentingan dan untuk menyediakan satu sumber data, sebuah database/ sistem yang dapat dipercaya setiap pihak. Dengan menggunakan smartcontracts, muzaki sebagai kontributor akan semakin mudah mengakses pendistribusian secara transparan. Selain itu, tingkat kepercayaan kepada amil juga akan meningkat. Lembaga zakat juga tidak memerlukan biaya audit monitoring yang cukup mahal, dan otoritas pengawas zakat akan terbantu dengan mudahnya sistem pengawasan. Di sisi lain, dana dapat terdistribusi dengan baik hingga sampai pada tangan mustahiq penerima zakat. Selanjutnya, sistem zakat dengan blockchain memiliki potensi yang signifikan dengan percepatan nilai dan penerimaan dana.

\section{e. Kemampuan Indonesia Mengadaptasi Digital System}

Dari segi pengumpulan dan pengelolaan dana zakat, OPZ secara umum telah memiliki strategi yang mulai beradaptasi dengan digital aspect. Digitalisasi pada proses pengumpulan dana zakat dilakukan melalui berbagai fasilitas diantaranya website, aplikasi berbasis android hingga mesin otomatis seperti mcash.

Pada aspek proses pengelolaan dana zakat, lembaga zakat telah melakukan proses digitalisasi dalam rangka meningkatkan proses good governance, tingkat akuntabilitas, dan efisiensi. Sebagai contoh, BAZNAS telah melakukan kerjasama dengan salah satu perusahaan fintech bernama Desto dalam membuat aplikasi zakat berbasiskan teknologi. Aplikasi tersebut dinamakan iZakat dan diluncurkan perdana pada tahun 2018 pada acara tahunan World Zakat Forum (WZF) di Malaysia. Hal ini sebagai salah satu upaya dalam melakukan proses digitalisasi pada aspek manajerial OPZ (Badan Amil Zakat Nasional, 2020). Dari segi pendistribusian dana, adaptasi teknologi yang telah dilakukan berupa bentuk pembuatan nomor identifikasi mustahik bekerjasama dengan Kementrian Sosial dalam memanfaatkan Basis Data Terpadu (BDT), sehingga OPZ dapat menyalurkan dana zakat secara efektif tanpa terjadi tumpang tindih dengan bantuan serupa.

Pada prakteknya, BAZNAS sebagai lembaga zakat terbesar di Indonesia, telah menerapkan system digital fundraising strategy melalui beberapa platform yaitu komersial dan platform non-komersial seperti aplikasi crowfunding dan payment point, innovative platform, sosial media dan artificial intelligence platform. Selain itu, dalam data menunjukkan bahwa kontribusi penerimaan dana zakat melalui digital terus mengalami peningkatan, dari yang tadinya hanya sebesar $1 \%$ pada tahun 2016 menjadi sebesar 24\% pada tahun 2020 (Beik, 2020).

Selain itu, sistem blockchain sendiri sewajarnya telah dapat digunakan di Indonesia. BAZNAS sedang dalam proses menerapkan basis teknologi bolckchain dalam manajemen pengelolaan zakatnya yang pada tahun 2020 berada pada tahap 1 (tahapan awal). Tahap ke 2, diproyeksikan pada tahun 2021 BAZNAS telah dapat menerapkan fitur secara lengkap. Selanjutnya pada tahun 2022 tahapan 3 yaitu networking, diproyeksikan platform ini dapat diterapkan secara keseluruhan pada BAZNAS di tingkat provinsi maupun daerah.

Tantangan selajutnya, dengan besarnya potensi yang dimiliki, Indonesia perlu untuk membentuk suatu platform digital blockchain yang dapat menjadi penghubung antara mustahiq, amil dan muzaki serta seluruh aspek pelayanan zakat ke dalam satu aplikasi, sehingga nantinya ekosistem per-zakatan secara nasional akan terbuka lebih luas. 
Lembaga zakat dapat dengan mudah menarik muzaki dengan mencantumkan program kerja melalui lembaganya. Melalui pendataan, mustahiq yang sesuai/memenuhi persyaratan dapat melakukan pendaftaran diri melalui platform yang dibentuk dan menyebutkan kebutuhan-kebutuhannya. Dari sisi pemberi donasi, muzaki dapat memilih untuk menyalurkan dananya kepada OPZ sesuai dengan preferensi masing-masing muzaki. Lebih jauh, seluruh laporan pengelolaan zakat dapat disajikan secara real time, sehingga nantinya inovasi teknologi dapat melahirkan integrasi nasional database perzakatan dan menciptakan big data zakat.

Indonesia sebagai salah satu negara di Asia Tenggara yang menjadi pusat pengembangan industri ekonomi islam di dunia, memiliki kekuatan antara lain, 1) mayoritas penduduk muslim, 2) dukungan penuh dari pemerintah, 3) kelembagaan zakat yang besar dan 4) komitmen pengelola lembaga zakat.

Berdasarkan tantangan dan kekuatan yang dimiliki, berikut beberapa strategi yang perlu dilakukan untuk mewujudkan potensi yang ada:

1. Peningkatan Kapabilitas SDM Lembaga Zakat

Lembaga zakat di Indonesia masih menemukan tantangan dari segi kelembagaan dan pengelolaan dana zakat. Hasil penelitian yang dilakukan oleh Sulastiningsih dan Utami (2013), tentang strategi pengumpulan dana zakat pada OPZ di Yogyakarta, berkesimpulan bahwa citra OPZ di Yogyakarta masih minim dan rendah. Hal tersebut disebabkan muzaki masih meragukan perilaku dan mental SDM zakat/aparat, data-data yang kurang akurat, lembaga zakat belum menginventarisir data dengan baik, serta kualitas SDM lembaga yang kurang baik karena kemampuan dan keterampilan manajemen untuk mengelola lembaga belum berkembang di kalangan pengurus lembaga. Di sisi lain, pemberdayaan para mustahiq penerima zakat melalui bimbingan OPZ belum dilakukan secara intensif dan maksimal.

Fenomena tersebut memperlihatkan perlu adanya pembenahan mindset pada
SDM lembaga zakat mengenai fungsi utama SDM lembaga zakat sebagai mediator amal sholeh. Paradigma etos kerja islami dengan bekerja optimal dan ikhlas yang bertujuan utama mencari ridha Allah, apabila diterapkan secara maksimal tentu dapat memberikan implikasi baik terhadap kinerja OPZ. SDM lembaga zakat sebagai fasilitator umat, mempunyai peran mulia tetapi juga tanggung jawab yang besar yaitu untuk dapat menyampaikan amanah publik baik dari segi penerimaan maupun pendistribusian dana zakat dapat terealisasi dengan baik dan benar, sehingga pada akhirnya dengan transparansi yang tinggi, dapat meningkatkan kepercayaan muzaki dan masyarakat.

2. Peningkatan Kesadaran Wajib Zakat dan Digitalisasi Zakat

Terdapat beberapa alasan yang menyebabkan orang enggan membayar zakat antara lain, tidak memiliki pengetahuan akan manfaat besar dari zakat, memiliki ketakutan bahwa dana yang disumbangkan akan disalah gunakan oleh pihak pengumpul dana, kurang tegasnya UU terkait zakat, minimnya kepercayaan pada lembaga terkait dan terdapat mindset bahwa membantu sesama tidak mesti melalui perantara zakat.

Rendahnya kesadaran masyarakat muslim dalam membayar zakat memiliki keterkaitan dengan keimanan dan pengetahuannya mengenai zakat. Sosialisasi tentang kesadaran pentingnya membayar zakat dapat menambah pengetahuan dan lebih jauh lagi, meningkatkan keimanan umat islam.

Meskipun zakat merupakan rukun Islam dan wajib untuk ditunaikan, tidak semua masyarakat paham akan peran zakat yang mampu mendorong perekonomian negara. Aspek kesejahteraan dari suatu bangsa tercermin ketika tingkat kesenjangan sosial dan angka kemiskinan kecil. Dengan dana zakat yang terhimpun secara optimal dan terdistribusi secara maksimal, dapat menghapus rantai kemiskinan, meningkatkan kualitas 
hidup masyarakat dan kemudian memberikan kesejahteraan sosial.

Selain itu, sosialisasi secara masif terhadap digitalisasi zakat sangat perlu untuk dilakukan. Masyarakat perlu diberikan pemahaman bahwa dengan sistem digital seperti blockchain pengelolaan zakat justru akan lebih efisien. Digitalisasi zakat mampu meningkatkan keamanan pengumpulan, pengelolaan zakat, dan mengurangi biaya yang selama ini dikeluarkan dalam transasksi. Amil bersama-sama dengan pemerintah perlu membuat gambaran sosialisasi zakat digital yang mudah dipahami oleh masyarakat.

3. Kerjasama Terintegrasi Antar OPZ

Data tahun 2017 menunjukkan jumlah organisasi/lembaga pengelola zakat di Indonesia sebanyak 603 lembaga. Jumlah tersebut terdiri dari 548 BAZNAS (48 BAZNAS provinsi dan 514 BAZNAS kabupaten/kota) dan 55 LAZ (19 LAZ nasional, 11 LAZ provinsi, dan 25 LAZ kabupaten/kota) (Badan Amil Zakat Nasional, 2018).

Pada realitanya masih banyak organisasi dan lembaga zakat pada masjid-masjid daerah yang tidak terlacak keberadaan dan jumlahnya. Untuk dapat memaksimalkan peran zakat, negara perlu memiliki database seluruh organisasi yang berperan dalam menghimpun dan mendistribusikan zakat.

Dengan adanya data yang saling tersingkron, pemerintah akan lebih mudah melihat potensi dan realisasi pengelolaan dana secara rill. Selain itu, pendistribusian zakat dapat lebih luas dan merata, bantuan tidak hanya menumpuk pada mustahik tertentu dan tidak sebatas pada daerah tertentu. Dengan adanya data yang saling terintegrasi, pihak pemerintah akan lebih mudah mengawasi dan mensosialisasikan apabila menerbitkan peraturan-peraturan terkait.

4. Melakukan Kerjasama Dengan Berbagai Platform Digital Guna Memudahkan Muzaki

Salah satu hal yang dinilai penting dan berdampak positif pada penerimaan dana zakat adalah memberikan kemudahan kepada muzaki dalam menunaikan kewajibannya. Kerjasama yang telah terjalin dengan sejumlah platform e-commerce digital saat ini sudah tergolong baik meskipun masih memerlukan beberapa peningkatan. Marketplace yang telah bekerjasama dengan OPZ dalam menerima zakat seperti Tokopedia, Bukalapak, dan Blibli.com, dalam aplikasinya perlu untuk lebih dimaksimalkan agar nantinya dapat memudahkan dan memberikan lebih banyak pilihan bagi para wajib zakat dalam melakukan pembayaran zakat.

\section{Kesimpulan}

Kehadiran sistem digital, dalam hal ini blockchain, merupakan sebuah fenomena yang muncul karena adanya keinginan transaksi yang lebih terpercaya, aman dan transparan. Implementasi blockchain pada lembaga zakat menjadi sebuah urgensi karena dinilai dapat meningkatkan kepercayaan seluruh stakeholder mulai dari muzaki, amil hingga mustahiq. Dengan perkembangan teknologi yang dinamis, maka penghimpunan dan pendistribusian zakat akan lebih sistematis dan dapat lebih ditingkatkan karena blockchain menawarkan konsep desentralisasi data yang permanen, rela-time, aman dan transparan sehingga dapat mengatasi stabilisasi sistem keuangan non-bank, termasuk lembaga OPZ dalam kegiatan mengelola dana zakat.

Potensi penggunaan teknologi blockchain dapat membantu mengatasi masalah ekonomi negara dalam hal pengentasan kemiskinan dan mencapai keadilan sosial, di mana data dapat diakses secara global yang memungkinkan untuk melacak pengumpulan dan pendistribusian zakat secara keseluruhan. Teknologi tersebut akan memastikan donasi dan pendanaan zakat sampai kepada penerima yang tepat.

Indonesia sebagai negara pionir dalam ekonomi Islam dengan potensi yang ada, dirasa mampu untuk beradaptasi dengan sistem ini. Aturan dan pedoman yang jelas mengenai hal ini di tingkat lokal, regional dan internasional akan ideal untuk mengoptimalkan teknologi blockchain 
misalnya dalam dompet digital untuk dipatuhi. Namun, para cendikiawan muslim perlu membuat strategi yang jelas dan rapi mengenai beberapa aspek teknis seperti smart contract sehingga model ini dapat dikembangkan baik untuk instansi zakat maupun untuk cabang keuangan Islam lainnya. Beberapa hal yang dapat diupayakan dalam mendorong praktik ini adalah dengan peningkatan kapabilitas SDM lembaga zakat, peningkatan kesadaran zakat dan konsep digitalisasi zakat, kerjasama terintegrasi antar OPZ, serta melakukan kerjasama dengan berbagai platform digital. Diharapkan penelitian selajutnya dapat menggali lebih dalam dan memberikan gambaran serta model smart contract atas penerapan sistem blockchain pada lembaga zakat yang relefan dan dapat diterapkan di Indonesia.

\section{Daftar Pustaka}

Ahmed Shaikh, S., \& Ghafar Ismail, A. (2017). Role of Zakat in Sustainable Development Goals. International Journal of Zakat, 2(2), 1-9. https://doi.org/10.37706/ijaz.v2i2.21

Azam, M., Iqbal, N., \& Tayyab, M. (2014). Zakat and Economic Development: Micro and Macro Level Evidence from Pakistan. Bulletin of Business and Economics, 3, 85-95.

Badan Amil Zakat Nasional. (2018). Statistik Zakat Nasional 2017.

Badan Amil Zakat Nasional. (2020). Outlook Zakat Indonesia 2020. Jakarta: Pusat Kajian Strategis BAZNAS.

Badrudin, R. (2015). Evaluation of The SpecifAc Allocation Fund for Indonesian Society Welfare. International Journal of Applied Business and Economic Research, 13(7), 5607-5624.

Beik, I. S. (2020). The Use of Technology in Zakat Management: BAZNAS Experience. 4th International Conference of Zakat. BAZNAS: Indonesia. https://doi.org/10.37706/iconz.2020

Buterin, V. (2015). Visions Part I: The Value of Blockchain Technology. Diambil 11 November 2020, dari Ethereum Blog website:

https://blog.ethereum.org/2015/04/13 /visions-part-1-the-value-ofblockchain-technology/

Dapp, T. (2014). Fintech-The Digital

Revolution in The Financial Sector.

Dalam Deutsche Bank Research (No.

1). Germany.

Davidson, S., Filippi, P. De, \& Potts, J. (2016). Economics of Blockchain. Public Choice Conference 2016, (May), 1-24. http://dx.doi.org/10.2139/ssrn.27447 51

Elasrag, H. (2019). Obstacles Challenges Blockchains for Islamic finance. Munich Personal RePEc Archive, (92676).

Firmansyah. (2009). Potensi dan Peran Zakat Dalam Mengurangi Kemiskinan: Studi Kasus Jawa Barat dan Jawa Timur. Jakarta: Lembaga Ilmu Pengetahuan Indonesia.

Khaf, M. (1987). Zakah Estimation in Some Muslim Countries. Jeddah: Islamic Research and Training Institute of The Islamic Development Bank.

Komite Nasional Ekonomi dan Keuangan Syariah. (2020, Mei 6). Gerakan Platform Digital Maksimalkan Donasi Masyarakat. Diambil 9 September 2021, dari https://knks.go.id/berita/244/gerakanplatform-digital-maksimalkandonasi-masyarakat?category $=1$

Komite Nasional Keuangan Syariah. (2019). Pemerataan Zakat Untuk Kesejahteraan Masyarakat. Insight: Buletin Ekonomi Syariah, (3), 1-24.

Kurniawati. (2004). Kedermawanan Kaum Muslimin: Potensi dan Realita Zakat Masyarakat di Indonesia (Cet.1). Jakarta: Piramedia.

Lipka, M., \& Conrad, H. (2017). Why Muslims Are the World's Fastest Growing Religious Group. Diambil 5 November 2020, dari Pew Research Center website: http://www.pewresearch.org/facttank/2017/04/06/whymuslims-arethe-worldsfastest-growing-religiousgroup/

Manhat, N. I., \& Waroka, A. (2013). Investigation on Zakat as an Indicator for Moslem Countries' Economic Growth. Journal Global Business Advancement, 6(1), 50-58. 
https://doi.org/10.1504/JGBA.2013.0 53478

Nor, R. M., Rahman, M. M. H., Rahman, T., \& Abdullah, A. (2017). Blockchain

Sadaqa Mechanism Frajor Disaster Aid Crowd Funding. Proceedings of the 6th International Conference on Computing and Informatics:

Embracing Eco-Friendly Computing, Kuala Lumpur, 25-27.

Pew Research Center Religion \& Public Life. (2015). The Future of World Religions: Population Growth Projections, 2010-2050. Pwe Research Center, 2010-2050.

Rahim, S., \& Kaswadi, H. (2014). An Economic Research on Zakat Compliance Among Muslim's Staff in Unimas. 53-65. Kuala Lumpur: International Conference on Masjid, Zakat, and Waqf.

Rejeb, D. (2020). Blockchain and Smart contract's contributions to Zakat management system. International Conference of Zakat, 15-24.

Salleh, W. N., Abdul Rasid, S. Z., \& Basiruddin, R. (2019). Towards Transforming Zakat Collection and Distribution Roles Using Digital Wallet in Support of Social Justice and Social Financing. Open International Journal of Informatics, 7(2), 95-103.

Santoso, B., Amilahaq, F., Ahmad, S., \& Nasir, N. E. M. (2020). Study on Block-Chain Implementation in Zakat Management (Case Study in Indonesia). ICIC 2020: Proceedings of the 1st International Conference on Islamic Civilization, ICIC 2020, 27th August 2020, Semarang,
Indonesia, 232. European Alliance for Innovation.

Sarea, A. (2012). Zakat as a Benchmark to Evaluate Economic Growth: An Alternative Approach. International Journal of Business and Social Science, 3(18), 242-245.

Shalihati, F. (2010). Analisis Presepsi dan Sikap Muzzaki Terhadap Badan Amil Zakat Nasional di Kota Jakarta. Institut Pertanian Bogor.

Stevans, L., \& Session, D. (2008). The Relationship Between Poverty, Economic Growth, and Inequality Revisited. Journal of Income Distribution, 17(1), 5-20.

Sulastinigsih, \& Utami, S. (2013). Strategi Pengumpulan Zakat pada OPZIS Daerah Istimewa Yogyakarta dalam Upaya Pengentasan Kemiskinan. Seminar Nasional dan The 2nd Call For Syariah Paper (SANCALL), 264-276. Syariah Paper Accounting UMS. https://doi.org/ISSN 24600784

Teerlink, M. (2019). Creating Transparency and Accountability in Nongovernmental Organisations Using Blockchain Technology. Utrecht University.

United Nations. (2020). Blockchain applications in the United Nations system: Towards a state of readiness (Vol. 7).

Yusoff, M. (2011). Zakat Expenditure, School Enrollment, and Economic Growth in Malaysia. International Journal of Business and Social Science, 2(6), 175-181. 